\title{
Doctor Armando Alonso Álvarez: A Unique and Unrepeatable Rorscharchista
}

\author{
Jesús Dueñas Becerra \\ Department of Psychology, Center for Studies of the Archdiocese of Havana, Cuba \\ *Corresponding author: Jesús Dueñas Becerra, Department of Psychology, Center for Studies of the Archdiocese of Havana, Cuba. \\ To Cite This Article: Jesús Dueñas Becerra. Doctor Armando Alonso Álvarez: A Unique and Unrepeatable Rorscharchista. Am J Biomed Sci \& Res. \\ 2019 - 1(1). AJBSR.MS.ID.000509. DOI: 10.34297/AJBSR.2019.01.000509
}

Received 奜: January 12, 2019; Published 非: January 18, 2019

\section{Editorial}

First of all, I want to thank the teacher, Master of Science, Miriam González Llaneza, who invited me to evoke the memory of Dr. Armando Alonso Álvarez, (1946-2017) whose name honors this Rorschachian event par excellence.

I would like to begin my presentation with one of the anthological phrases of Professor Alonso Álvarez: «an adequate diagnosis of personality [shows] the way to offer the best alternative of help.

Armando Alonso Álvarez, Ph. D., assistant professor of the Faculty of Psychology of the University of Havana, started, from three years ago, to the infinite space to meet with the Universal Spirit; leitmotiv in the poetic-literary and journalistic work of the Apostle, an ethical reference that will guide his steps in the exercise of pre and postgraduate higher teaching, especially in the teaching of Rorschach Psychodiagnosis; discipline excluded from the curricular design of the Psychology career in the 70s of the last century and resurrected by the also honorary president of the Cuban Society of Rorschach, in the decade of the 90s of the last century.

Although the first Rorschach teacher in the capital Alma Mater, after the revolutionary triumph of January 1959, was Dr. Noemí Pérez Valdés (1926-2008), founding professor of the School (now Faculty) of Psychology, Dr. Alonso Álvarez followed in the footsteps of her venerated teacher and therefore, resumed the teaching of that method of personality research, scientifically and artistically designed by the brilliant Swiss psychiatrist Hermann Rorschach, so that such a valuable instrument would not be buried in the dark shadows of oblivion.

Professor Alonso Álvarez joined me with solid professional and affective-spiritual ties, since we shared academic responsibilities in the Rorschach Module and Projective Techniques, which he taught in the Master's Degree in Clinical Psychology, in the School of Psychology; educational-postgraduate educational activities to which I had the immeasurable kindness of inviting me to present the findings of the Rorschach Psychodiagnostic research, organic signs and digital EEG, carried out by the neurophysiologist, Ariel Faure Vidal, M.D., and the author of this literary evocation as a rorscharchist.

We coincide - on several occasions - in scientific events on Rorschach sponsored by the Havana School of Psychology, as well as by the Cuban societies of Psychology and Health Psychology, whose membership we integrate; and also, I was a professor of Applied Psychology for his first-born son, the graduate. Damián Alonso, in the postbasic in Clinical-Surgical Nursing, that he studied in the Hermanos Ameijeiras hospital; situation that contributed - and in what way! - to further strengthen our relationship on a personal level.

Alonso Álvarez was a professor of many of the rorscharchistas who today apply Psychodiagnostics as part of the care, educationaleducational and research activities they carry out in their respective contexts.

The psychologists who had the privilege of being his disciples discovered in that exceptional educator, both in the classroom, and outside of it, the ethical-humanistic and spiritual values that should characterize the personality of a professional of the Martian science of the spirit, respect to Psychology as a science and profession, to Psychodiagnosis in general, and to Rorschach in particular.

My mnemic archive evokes what Professor Alonso Álvarez reiterated to the point of exhaustion in classes or in an informal 
exchange with students and colleagues: «the most important thing when it comes to qualifying and interpreting the Rorschach protocol, is the qualitative analysis of the answers given by the examinee»

I shared with him - by telephone - many moments during the evolution of the lethal affection that would take him, finally, to the grave. These conversations, recorded in my poetic memory, have become a great experience of human and spiritual growth for me. With how much integrity and dignity it remained until the end of its relatively short earthly existence.
On the other hand, he was able, in the precarious health conditions in which he was, to advise pre and postgraduate theses, write articles for specialized journals and a book: Psychopathology for psychologists (in the process of editing). These tasks and the care he received facilitated the quality of life necessary to increase his curriculum vitae, which includes the work of a lifetime; professional work that can show the sky with legitimate pride. 